\title{
Public involvement processes in forest management in Canada ${ }^{1}$
}

\author{
by Glen Blouin ${ }^{2}$
}

Eighty-five percent of Canadian forests are owned by the provinces; the balance is owned by the federal government ( $9 \%)$ and private individuals and corporations (6\%). Provincial crown forests have traditionally been managed by the forest industry under long term agreements with the provinces, primarily to meet timber objectives. Recent trends towards forest management for both timber and non-timber values have led to greater public involvement in decision-marking. Canadians have input into management of all three forests indirectly via laws and regulations, and directly by public participation. A variety of processes for public involvement are underway. The cornerstones to success are: equitable representation; access to information; fair and open processes; and informed participants.
Les provinces assument la gestion de $85 \%$ des forêts canadiennes; la différence étant sous la responsabilité du gouvernement fédéral $(9 \%)$ ou la propriété d'individus ou de corporations (6\%). Les forêts publiques provinciales ont été aménagées traditionnellement par l'industrie forestière en vertu d'ententes à long terme avec les provinces, principalement pour répondre à des besoins en matière ligneuse. Les récentes tendances en matière d'aménagement forestier à des fins de production de matière ligneuse et pour des valeurs autres que le bois ont engendré une participation plus accentuée du public dans les processus de prise de décision. Les Canadiens ont droit de regard sur les trois tenures forestières indirectement par l'entremise des lois et règlements, et directement par la participation du public. Plusieurs types de processus de participation du public existent actuellement. Le succès de ces processus reposent sur la représentation équitable, l'accessibilité à l'information, des processus honnêtes et ouverts, et des participants informés.

\section{Introduction}

The people must take a greater interest in the welfare of the forest. Under our democratic system it is the privilege of every citizen to participate actively in this program ... it is the duty of those familiar with forest values to express public opinion for the guidance of governments. (Canadian Forestry Association, 1943.)

These words, written over fifty years ago, demonstrate that the concept of public participation is not a new phenomenon in Canada. In fact, the Canadian Forestry Association (CFA), the pioneer of forest conservation in Canada, has been advocating greater public involvement in forest decision making since it was founded in 1900 .

But public interest in forest conservation was actually stronger at the beginning of this century than it was even as little as ten years ago. For example, in the 1920 s it was not uncommon for upwards of 600,000 Canadians to attend local CFA conservation lectures in a single year. People flocked to the touring CFA/CPR railway car in western Canada, and to the small town churches, town halls, and theatres of eastern and central Canada when the conservation "evangelists" made their annual appearance, armed with pamphlets and crude (by today's standards) films.

If the turn of the century can be described as a peak in the mainstream conservation movement, then the middle of the century must be characterized as a valley. Somehow, with the urbanization of average Canadians and their preoccupation with making a living, raising a family, and seeing to immediate and

\footnotetext{
"Paper presented at the "Forestry Towards The 21st Century" Symposium, sponsored by the Chinese Society of Forestry and the Canadian Institute of Forestry, Beijing, 11-16 June 1997.

${ }^{2}$ Executive Director, Canadian Forestry Association, 185 Somerset Street West, Suite 203, Ottawa ON K2P 0J2.
}

future material needs, much of this sense of resource stewardship, much of the interest in the welfare of the forests, waned. We'll come back to this in a moment.

\section{Forest Ownership in Canada}

But first, let us examine the ownership patterns of Canadian forests. There are three types of ownership of the forest. A relatively small amount of the 417 million hectares - six percent - is in private ownership, held by some 425,000 private woodlot owners whose holdings average about forty hectares, and by a handful of forest industry corporations. The second component is federal government forest, owned by Canadians and entrusted to various federal departments such as National Parks and National Defence, and comprises nine percent. The vast majority -85 percent of the productive forest - is owned by the general public through the ten provincial governments, and is referred to as provincial crown land.

Canadians have some degree of input into the land use and management of all three forests through a web of federal, provincial and municipal laws and regulations, which cover an array of issues such as waterways, wildlife, pollution, etc. But essentially private landowners are free to manage - or not manage - their holdings in keeping with their own objectives, and they wish to keep it this way. On federal and provincial government land, the public has indirect influence via election of officials who, theoretically at least, implement their wishes, and by lobbying those officials and the civil servants who serve under them.

The focus of this paper is on provincial crown land, and the degree to which citizens participate in decision-making with regard to its use and management.

\section{The Rise of Public Participation}

By the 1950s and 1960s decisions about land use and forest management on provincial crown land had become almost 
the exclusive domain of the forest industry and the provincial governments - the primary users of the forest, and the people who represented those who owned it. Some have suggested that this was some sort of clandestine behind-closed-doors arrangement. It wasn't. Yes, the doors were closed, but simply because no one else thought to knock. It was merely a case of the industry working to secure their long-term timber supply, keep their mills going and make a profit; and the government wanting to generate regular royalties, derive tax revenue, ensure employment and community stability, and maintain some minimal level of control over the resource they were elected to oversee.

The rest of the public was on the outside, but not looking in. They were pre-occupied elsewhere and generally apathetic. They took our forests for granted.

Things were rather simple then. The objective of forest management was sustained yield of timber and, to a much lesser extent, the conservation of a few of the wildlife species that were valued for hunting. There was little or no talk of biodiversity, of ecosystem management, of endangered species, of protected areas (other than National Parks), of sacred aboriginal lands, of old growth forests. These concepts were not part of the vocabulary of either foresters or the general public. They are now.

With the broadening of values held and non-timber benefits expected from the forest, there are now more players in the game - Canadians who had previously rarely, if ever, directly participated in decision-making exercises.

The phenomenon of the public participation process, although dating back perhaps to the rise of democracy in western civilization, and perhaps rooted as well in North American aboriginal cultures, has come to the fore in Canada only in the last decade. It has developed for a number of reasons, including: reaction to the over-centralization of governments and the isolation of the bureaucracy from local realities; the rise of the consumer revolution, and the peace, civil rights and environmental movements; the higher level of education among the general public; the pervasiveness and influence of the mass media; and in the forest management arena, the recognition of the many values and benefits the forests provide other than timber. What has resulted is a shift from representative democracy whereby elected officials act on behalf of the citizens, towards participatory democracy where citizens effect decisions autonomously (Roberts 1995).

In eastern Canada public interest seemed to begin with reaction to the controversial aerial spraying of insecticides in the 1970s. It became a wake-up call to the public. Concern over spraying of chemicals on people, waterways, and wildlife, as well as forests, created a realization that things were being done in and to our forest over which the public had little input or control. And the perception was that some of these things might not be beneficial.

The attitude of citizens underwent a dramatic transformation. They became uncomfortable with the complete trust they had placed in technology and big business and government. They became more critical. They began to demand opportunities to have the options explained before decisions were made. They began to demand evidence that decision makers had considered all the social, cultural, economic and environmental issues, not just the business and political issues. And ultimately they demanded to become decision-makers themselves.
Meanwhile, public access to previously inaccessible areas, particularly on the west coast, exposed people to mountainside clearcuts where beautiful forests had once stood; a shock to the aesthetic sensitivities of those who personally saw them or witnessed images of them in media reports.

Out of these initial concerns there evolved a movement, a part of the whole North American environmental movement which unfolded in the wake of 1960 s counter culture and inflammatory and catalytic exposés such as Silent Spring (Carson 1962):

Increasingly Canadians are saying "These are our forests. We as Canadians own them. We want to have a say in what happens to them. We want to participate in the decision making processes."

And governments responded. Curiously, the radical, and generally dismissed, "power to the people" youth anthem of the sixties has finally become legitimized in what governments promote today as "empowerment" of the people. This represents a major shift from a minority held view to a commonly accepted, politically correct principle, in less than thirty years. It could be argued that one of the factors in this phenomenon was the maturing of the so-called "baby boomer" generation to the decision-making power structure of today.

\section{The Essential Ingredients}

There are four cornerstones to an effective public participation process:

First is equitable representation of all interests, encompassing the views of a full range of interested parties and a full range of values. The ultimate outcome is partnerships rather than conflict. This implies trust, absence of hidden agendas, and commitment to equitable solutions. This is not easy.

Second is access to relevant information on economic, ecological, social, cultural and other relevant impacts, such as health and safety.

Third is acceptance by participants that the decision-making process is fair, open and effective, with recognition by all parties of the principles of democratic participation, respect for diversity and plurality of opinion, and agreed upon conflict resolution through dialogue, negotiation, and compromise.

Informed participants are the final cornerstone, reflecting the belief that informed decision-makers will make informed decisions. Education is key.

\section{The Benefits and Costs}

The benefits to be derived from public participation are as follows:

1. More insightful decisions which reflect a broader range of public concerns, interests and values.

2. Reduction or avoidance of conflict and confrontation resulting from decisions, and public support for and ownership of the decisions taken.

3. Increased credibility of the forest management planning process.

4. Education of all parties involved.

The disadvantages lie chiefly in the area of time and money required to undertake a valid process, the uncertainty of success in a relatively new area of experimentation, and, to those who traditionally have unilaterally made such decisions, a loss of control over the decisions and the need to compromise in fulfilling their own objectives. 


\section{Some Examples}

So what processes are underway in Canada to implement public participation in forest management decision-making? As stated earlier, there is a variety of local, regional, provincial and national processes, and they are all structured in response to unique social, historical, political and biological characteristics of specific areas. Furthermore, they all involve varying degrees of public involvement, from simple oneway communication from industry to the public, to consultation, to true cooperative and shared decision-making, to citizen control.

To illustrate, I will cite several examples of the many processes today, and try to provide some broad geographic representation from east to west.

In the relatively small community of Miramichi, New Brunswick, in eastern Canada, Repap Paper Inc. initiated a consultation process in 1991 as part of the five-year update of its long term forest management plans, the latter a condition of its tenure of crown land with the provincial government. Over a one-year period the company held four one-day town hall meetings, and invited a broad cross section of interests to participate. Initially, the participants advised the company which values they wished to be derived from the forest. Company personnel and government foresters then analyzed how well they were performing in satisfying the seven values - which ranged from an ethic of respect of the forest, to jobs, to easily accessible information. They found some lacking, and set about to remedy the situation. A key to the success of the process was a series of company-conducted woodlands tours, which over five years brought four thousand citizens into the forest (O’Neill 1995). In 1997 Repap is planning to start the process all over again as their new five-year plan will be publicly reviewed.

A second example comes from the province of Québec. An experimental round table was established in 1994 to provide input into the five-year management plan of Abitibi Price. The pilot project invited representative intervenors from the hunting and fishing sector, the aboriginal community, tourism and recreation, trapping, and municipalities to voice their views on the company's management plans, and for the company and the provincial government to incorporate these views into the revised plans (Bertrand and Beaulieu 1995).

The third example is on a much larger and more formalized scale. In the province of British Columbia, the province with the largest trees and the most diverse ecosystems, government has been struggling with public participation processes since the 1970s. In 1992 the government created the Commission on Resources and Environment (CORE) to develop a land use strategy for the province. Until its dissolution in 1996, CORE set up four regional planning processes with representation from a broad cross section of sectors - including youth, conservation, industry, labour, tourism, local government and others - with the objective of achieving shared decision-making by consensus. Although it failed to achieve consensus in any of the four regions, the process has firmly established public participation as an integral part of land use and forest management planning in the province, with 60 percent of the forest currently falling within such processes.

\section{Conclusion}

Public participation is no longer an option. It is a reality in the nineties. In Canada, over ninety percent of the forests belong to the people of Canada, the taxpayers of Canada. Canadians are exercising their right to determine how their forests are managed via participatory democracy. Collectively, they own them. With that right comes responsibility. If average citizens wish to have input into how our forests are managed, then they must ensure they are informed. And if the forester wishes to be a legitimate participant then he or she must recognize there is more to managing an ecosystem than the traditional management and extraction of timber. A two-way dialogue is essential to the success of the process, and this necessitates listening to all legitimate and informed viewpoints.

As a result, better and more enlightened decisions will be reached, conflict will be avoided or reduced, a more holistic management of our forests will evolve, and the result will be a land use and forest management scenario which will achieve both the economic and ecological objectives necessary for sustainable development of the forest resource.

\section{References}

Bertrand, L. and V. Beaulieu. 1995. Consultation Between the Forest Industry and Local Interveners. In Canadian Pulp and Paper Association: 1995 Annual Meeting Report. Canadian Pulp and Paper Association. Montreal.

Carson, R. 1962. Silent Spring. Fawcett Publications, Inc., Greenwich, Conn.

O'Neill, J. 1995. Public Participation at Repap New Brunswick Inc. In Forest Forum Special Issue \#8 - Public Participation. Blouin, G and R. Comeau, eds. Canadian Forestry Association. Ottawa.

Roberts, R. 1995. Public Involvement: From Consultation to Participation. In Environment and Social Impact Assessment. Vanclay, F and D. Bronstein. John Wiley and Sons. 